\title{
The Covenant, Baptism and Children
}

\author{
by G. S. HARrison
}

THE HISTORIC BAPTIST view of the sacrament is fairly defined for us in the words of the 1689 Particular Baptist Confession of Faith:-

'Baptism is an ordinance of the New Testament, ordained by Jesus Christ, to be unto the party baptized, a sign of his fellowship with him, in his death and resurrection; of his being engrafted into him; of remission of sins; and of his giving up unto God, through Jesus Christ, to live and walk in newness of life.

Those who do actually profess repentance towards God, faith in, and obedience to, our Lord Jesus Christ, are the only proper subjects of this ordinance' (xxix. i, ii).

Upholders of this view are opposed on many grounds, but, in my opinion, the argument based on the covenant is the only one with which Baptists have seriously to contend. The covenant argument is a substantial one, indeed a very substantial and formidable one. Once grant its premises and its conclusions would seem to follow fairly logically and inevitably. As the reader will appreciate there is a considerable measure of readjustment to be undergone by anyone dealing with this covenant argument from an attitude so markedly different from it as mine is. It may well be that some of my criticisms are misdirected because of this strangeness. Such as they are these criticisms will be centred largely around the implications in the realms of ecclesiology and sacramental administration. It is interesting to note at this point something that Marcel writes: '... our Baptist brethren will only achieve their task if they succeed in carrying through a theological, that is to say, scientific and biblical, attack not only on the other constitutive elements of the covenant which we shall study, but on the covenant itself. They must attack the very cause itself and not simply-for that 
would be an error of method-one or other of its consequences. We shall permit those who oppose infant baptism to take refuge neither in the subjective conclusions of their personal sentiment, nor in the shadow of history and its impositions, nor again in the criticism which is called modern and its self-styled "established" results, when, for reasons that are most disputable, they contradict or neglect data of Holy Scripture which are immediate and consequently of capital importance'. (The Biblical Doctrine of Infant Baptism, James Clarke, I953, pp.94f.). And again: "It is a fact of the greatest significance that in all the works written in support of the Baptist position inevitably an attack is found, sooner or later, against circumcision taken by itself, or pronouncements which cannot fail to convey a depreciation of its importance, a minimizing of its meaning and value-and that too in spite of the clearest and most unmistakable biblical textswhich tends to produce a crude and misshapen caricature of circumcision' (ibid., p.92).

There is much that is true in Marcel's words, and I do not know of a modern work on Baptism, written by a Baptist, which is not fairly condemned by them. The latest and most thoroughgoing is that by R. E. O. White, The Biblical Doctrine of Initiation, (Hodder and Stoughton, 1960). Here is a writer who has read Marcel and who presumably recognizes the force of the covenant argument. It is a mark of the cogency of that argument (or more likely, of the quite untheological nature of White's method), that he can dispose of it only by falling back on what in any case many would consider to be a naïve, outmoded liberal view of $J, E, D$ and $P$, and making circumcision in, for example, Genesis xvii a post-exilic Priestly ritual bolstering the interests of narrow Jewish exclusiveness. Thus circumcision is robbed of its divine origin and the covenantal significance that the Old and New Testaments repeatedly ascribe to it. It is no part of the theological method to discard or rationalize those portions of Scripture which do not fit in with your theories. Clearly, any argument against infant baptism which by implication supposes that all good Bible believing Baptists could have had no answer to Paedo-Baptists until the advent of liberal criticism in the nineteenth century is no argument at all. There is a patent need for a biblical and theological account by a 
contemporary Baptist-an account that will neither eviscerate the covenant nor despise circumcision.

Fundamental to the whole argument is the belief that the covenant is one. There is not a succession of dispensations, each with its own appropriate little covenant. There was not one covenant with Abraham, others with Moses and David and then the great new covenant. On the contrary, the covenant is one. True, it has different manifestations. Consequently, its 'accretions', such as the rituals connected with the law of Moses, may vary, but its substance remains constant. The promise that was made to Abraham (Gen. xvii.7, 'And I will establish my covenant between me and thee and thy seed after thee in their generations for an everlasting covenant, to be a God unto thee, and to thy seed after thee') - that promise is the reiterated theme of all subsequent covenantal declarations. That God will be their God, and the people His people was the blessing promised to Abraham and to all in later generations with his faith. In one sense, then, the Bible knows of no higher blessing than this, and in fact Biblical history is the story of God working out this great purpose.

But it is not only the nature of the blessing promised in the Abrahamic coven ant that indicates its perpetuity. There are as well specific points in the New Testament at which this covenant is recognized as still existing. In the Magnificat (Luke i. 46-55) not the least of the causes of Mary's rejoicing lies in the fact that God 'hath holpen his servant Israel, in remembrance of his mercy; as he spake to our fathers, to Abraham and his seed for ever (vv.54f.). Then Zacharias, the father of John the Baptist, can bless God for performing the mercy promised to their fathers and for remembering His holy covenant, the oath which $\mathrm{He}$ had sworn to Abraham (Luke i. 72f.). Again, Galatians iii. $13-29$, is an important chapter for the covenant argument. There Christ is seen as the seed of Abraham to whom the promise was made, and through whom it was extended to the Gentiles. Moreover, the covenant with Abraham is seen to have been prior to and independent of the giving of the law. As a result the inheritance is of promise, not of law, and presumably the same promise, and therefore covenant, is in operation now. So then, the covenant is perpetual. 
This conclusion gains further support from the fact that the spiritual blessings enjoyed by Abraham and all the faithful in the Old Testament age were those supremely promised to Christians and given them by Christ and His work. As circumcision was to Abraham a seal of the righteousness of faith it is necessary to presume, as indeed Romans iv explicitly tells us, that he was justified and enjoyed full forgiveness of sins. And could sanctification be denied to such a person? Nor were the Old Testament saints without the very presence of God: it was a vivid reality to them, as is clear from many of the Psalms.

This is the first stage, then, in the covenant argument-to prove the unity, the persistence and the spirituality of the covenant of grace established with Abraham and sealed with 'the blood of the covenant', the blood of Christ.

It is then argued that this covenant was not established with a conglomeration of individuals. Instead it had a strong corporate aspect. That is quite basic. In the first place it had a family relationship. God promised to be the God of Abraham and his descendants, along a certain line. This family relationship naturally developed into a racial one as well, since these specified descendants of the Patriarch formed the Jewish nation-and this wasthe extent of thecovenant. They were God's covenant people. In fact, it is argued that they were the church of God in the Old Testament, and so Stephen calls them in Acts vii. $3^{8}$. Believers, their children, unbelievers - all were comprehended within this corporate designation, all were in the covenant, albeit some of them only externally in their flesh and not internally in their hearts. The temporary element of racial discrimination was to be thrown down at Calvary, but the family aspect of the covenant was to continue. However, whether you consider the individual family or the collection of families that together formed the nation it is still true that there was a two-fold aspect to this covenant. There were those who apparently were in it, and those who really, as well as apparently, were in it - the remnant, the elect, the true Israel. All Israelites were outwardly professors of the blessings of the covenant in virtue of their Abrahamic descent. To all these, not just to the spiritual élite, was circumcision, the seal of the covenant, given. Such was the sphere of the administration of the covenant. God repeatedly 
honoured His promise to Abraham and so this 'sphere' was the 'seed-bed' (Marcel) of the church. Now this, we are told, constitutes the perfect representation under which we should conceive of the church of God in all ages. Thus, even as the covenant is one in Old and New Testaments, so is the covenant people, the church. It would require a specific New Testament repudiation of this way of looking at things to cause us to abandon it. Such, it is held, we do not have.

Now, to all those who were in the covenant and therefore in the church it was proper to administer the seal of the covenant circumcision. All who joined the covenant people had, likewise, to be circumcized. It was quite inconceivable that those who were in the covenant should be denied this seal and mark of the covenant. Once more it is necessary to draw a distinction between the temporary and the permanent; in this instance between the manner of signifying and the thing signified respectively. Circumcision in its outward aspect, the cutting away of the flesh, was the former and was bound to pass away with the death of Christ. But that which was signified by this carnal act, namely the remission of sins, justification and regeneration, would find another symbol in the form of baptism. This connection between circumcision and baptism is made closer by an exegesis of Col. ii. I If. which virtually equates them, or equates at least their significances. In this way baptism becomes the new circumcision, the initiatory rite of the new covenant. It should be administered to the same people as circumcision was, with of course the specific differences indicated in the New Testament, e.g. women as well as men are to be baptized.

So now all those outside the covenant who repent and believe the gospel enter the covenant and receive its seal. The children of believers (presumably, of professed believers) since they are already in the covenant are entitled to baptism as well. When the church is in a period of rapid missionary advance and expansion (as in the New Testament age) the former mode (believer's baptism) will predominate. But in more usual and settled times it will be infant baptism that will be the more common, and in any case this form will be found whenever there are converts who are parents. 
It will be as well, perhaps, to say a word regarding the efficacy of baptism thus conceived. First of all, it is not necessary to suppose that anything happens to the child in the moment of baptism. Of course, the Holy Spirit may work regeneration in the child there and then, and in some way in connection with the sacramental administration. But this must be unlikely. However, this is no drawback to the real efficacy of baptism, for the time of operation of the sacrament is not limited to the moment of administration. Whenever in later life the baptized person recalls his baptism he should be driven to fulfil it - either by taking upon himself for the first time the obligations of the rite, or else by calling himself back to more serious and devoted outworking of them.

There is a vital principle resulting from this whole argument. It concerns the attitude which must be taken towards children who, outwardly at least, are in the covenant; and the manner and content of preaching to them. Often it has been held that until they indicate to the contrary it must be presumed that the things avowed of them in baptism are true. As a result they are to be regarded as Christians. They are not little heathen, but embryonic saints. Such a view is bound to have radical consequences for one's whole approach to children's work, and especially to their evangelization. The duties of the covenant are pressed upon them in the context of its privileges; and they are urged to be sure that they who are of the covenant are in the covenant.

Now all that, as I see it, is the basic outline of this whole argument with reference to the covenant. I have tried to develop it in five successive and consequent stages, (a) the covenant, (b) the church, (c) circumcision, (d) baptism, (e) the resulting view of children. What I propose to do next is to raise what are certainly challenges and what may be scriptural objections to this whole scheme. I do not want to raise issues which traditionally have resulted in a stalemate (although to some extent this may be inevitable), and so I will not linger with things like the onus probandi and the admission of women to the Lord's Supper. By way of preamble to all the objections let it be said that Baptists are unhappy about turning straight away to the Old Testament, and to what they deem a somewhat tortuous 
argument, to justify a New Testament ordinance - and one that could be numbered among the first principles of Christianity (Heb. vi. 2). Undoubtedly it is this, allied to the fact that the New Testament knows of no certain instance of infant baptism that lends plausibility to the Baptist point of view.

It is as well to mark the real point at issue, or first of all what it is not. Firstly, it is not, can children, or even infants, be saved? They can be and have been, and logically this no more proves that they are proper subjects of baptism than does the fact that heathen can be and have been saved prove that they should be baptized without other considerations. Nor, secondly, does the fact that, for example, John the Baptist (or Jeremiah) was regenerate from a very early age prove that all other children of believers should be baptized on the assumption that the same might be true of them. A third irrelevancy concerns the question of children (whether of believers or unbelievers) dying in infancy. Emotion usually prevails over logic and strict biblical exegesis in all of these questions, and I mention them only because they seem persistently to turn up in many accounts of the covenant argument. The question is rather, is the sacrament of baptism of such a nature that it not only may but also ought to be administered to a certain group of children?

Let us look at the covenant section of the foregoing argument, and in the first place at the question of the new Covenant. Now here we are always in a real danger of being impaled on one of the horns of the covenantal dilemma. Too often those who have tackled the problem of the relationship of the new covenant to the earlier covenant (or covenants) have veered either to the extreme of despising the old covenant, or to that of not acknowledging the superiority of the new. It is quite plain that the Old Testament saints enjoyed covenant blessings of salvation that were inward and truly spiritual, as all such blessings must be. To define the blessings of the new covenant solely in similar terms is in effect to detract from these pre-incarnation blessings. Yet to say too much of these former blessings is surely to render Jeremiah xxxi. 33 pointless. If you make this text the virtual substance of the Abrahamic covenant, then 'new' is a singularly inappropriate word for Jeremiah to use. But, on the other hand, if you tie these blessings of Jeremiah xxxi. 33 to a covenant that 
came in after Jeremiah then apparently you have stripped the Abrahamic covenant of all spirituality and have sundered an essential biblical unity.

There is another problem that arises in connection with this section. Is it axiomatic that the sign and seal of the covenant should be given to the same classes of people in both administrations, i.e. to children of professed believers? Is not the Passover - Lord's Supper consideration relevant here? Most people assume that the Passover was eaten by children (see Ex. xii) and that the Lord's Supper should be shared only by those of an age to understand what they are doing. There is no explicit change of administration, and it is difficult to believe that the couple of phrases 'not discerning the Lord's body' (I Cor. xi. 29) and 'let a man examine himself' (I Cor. xi. 28) are any more an explicit reversal of the Old Testament method than the persistent New Testament linking of professed faith with baptism. John Murray (in Christian Baptism, I952) at least recognizes this difficulty concerning the consistency of sacramental administration, but he suggests that the Passover was not eaten by infants and young children (not the least of their disqualifications being their lack of the necessary teeth!), but only by those capable of understanding what was meant by the ceremony. In theological substance this last point is all that the Baptist would claim concerning his view of baptism.

Again, it is perhaps well to realize that Reformed theologians have not been by any means of a common mind on the concept of the covenant itself. In particular there have been some very different ways of looking at the covenant with Abraham. Some have spoken in terms of a two-fold covenant, external (with the Jewish race) and internal (with Abraham and his spiritual seed), and there is much to be said in favour of such a view. But it is not a very big step from this to arrive at two covenants. Listen to Charles Hodge writing in the Princeton Review (October I853): 'There were two covenants made with Abraham. By the one his natural descendants through Isaac, were constituted a commonwealth - an external visible community. By the other, his spiritual descendants were constituted a church. There cannot be a greater mistake than to confound the national covenant with the covenant of grace, and the 
commonwealth founded on the one, with the church founded on the other. When Christ came the commonwealth was abolished ...' (pp. 684f.). Now that is probably not Hodge's final word on the subject, for he would prefer to speak in terms of external and internal aspects of the one covenant. Yet another variation on the theme is to attach the sacraments of the covenant to the external covenant (and not to the internal one) in such a way as to make those applying for the use of the sacraments not professors of regeneration and membership of the church invisible, but merely of the church visible. Thus is made a false distinction so that what ought to be two aspects of the church become virtually two churches, the one spiritual, the other social. This view usually goes hand in hand with a belief in the sacraments as converting ordinances. In God's grace they may become such on occasion, but in His declared intention they ought never to be regarded in that manner. The extraordinary ought never to determine the spiritual norm. Now I mention all these variations not by way of a study in historical theology, but just to try and draw out some of the problems connected with the covenant, with the people in it externally and internally, and with the question of who as a result are to receive its sacraments.

This leads on into the doctrine of the church that goes along with covenant theology. Now, many Baptists would find difficulty in speaking of Israel as the church of God - this despite Stephen's reference, already mentioned, in Acts vii. 38 and the LXX use of $\varepsilon x x \lambda \eta \sigma^{\prime} \alpha$ to translate qahal. They would infer from our Lord's response to the Petrine confession (Mt. xvi. I6ff.) that in some meaningful sense the church was a society of the future when those words were spoken. They would maintain as well that a more deliberate and conscious profession of faith was required in the New Testament for membership of the Christian church than seems to have been demanded in the Old Testament for membership of Israel. This, they say, was a mere racial assembly, composed of families it is true, but essentially a racial community which for all soteriological considerations ceased in the New Testament, even if there was a continuing family connection. Therefore, to call Israel 'the church' seems very far removed from that pure company of 
God's elect which formed the body and bride of Christ, and to which the visible manifestation ought closely to conform. But once again very careful definition is necessary if the errors of Marcion are not to receive a new lease of life.

However, even if you accept the fully developed covenant argument, whose children are to be baptized? The answer, of course, is those children who are in the covenant, which is in this case equivalent to saying, children one or both of whose parents are believers. But this last phrase must be re-cast so as to read 'children of professed believers', since we cannot with certainty pry into the parents' hearts. But what is a 'professed believer'? The question is more than academic. It is a particularly acute one in these days of a virtual complete lack of church discipline. The convenient contemporary answer defines such a person as one who has been baptized. But is this answer adequate? Many theologians have (rightly) stressed the importance of taking upon oneself on coming to years of understanding the obligations of the covenant - and this by wholehearted and active adult church membership and regular participation in the Lord's Supper. To refuse to do these things is in effect to uncovenant yourself and to sever yourself from the people of God. But the children of such uncovenanted people today form the bulk of the candidates for infant baptism. You have in effect if not in explicit theological statement, arrived back at the old Half Way Covenant - a covenant which drove a wedge between the two sacraments of the covenant and required more on your part spiritually for your admission to the Lord's Supper than it demanded of you for the baptism of your children. Theology wedded to convenience if ever it was! Someone thus baptized, as are most children today, would have no apparent right to his baptism. Do you rebaptize him on his own profession of faith as a believer, or do you fall back on the old theme of calling the church the child's Mother, and thereby cover a multitude of parental deficiencies?

We are dealing in reality with the fundamental nature of the church. Is it, or is it not, a 'gathered' church? This difference in ecclesiology has always been at the root of the Baptist objection, and to some extent Baptists have here been joined by the Congregationalists. The church is not a Volkskirche-a con- 
cept which was anathema to the Anabaptists of the Reformation and is so to Karl Barth of today. It is a community of those who are called out and who respond in faith to that call. Such at any rate is the Baptist contention. Its membership is not hereditary, nor is its entrance automatic in any respect, since a deliberate, conscious, open and credible confession of faith is called for on the part of those comprising it. Of course, always on this earth it will be permixtus, never consisting solely of regenerate persons. But at least it should markedly tend towards that aim and the aim should be aided by a measure of communal as well as individual investigation of the professor's claims. To all this, needless to say, it is objected that the practice is uncommendable even as the desire is unscriptural. The people of God in Old and New Testaments seemed to include some rather strange and anomalous individuals. And does not the parable of the wheat and the tares which grow together until harvest indicate that we are not to try to separate off these unregenerate people from the rest and prevent the former from entering the church? It was just this issue (plus his objection to the sacraments being regarded as converting ordinances) that led to Jonathan Edward's ejection. In the course of the controversy Edwards had to deal with the parable and the foregoing exegesis of it. In a word his attitude was that it had no relevance to the issue, since it was a parable not of terms of admission to the community but of continuance in it.

The question really is, where do you draw the line in applying the tests for membership? Ought the hearts of men to be probed for the presence of the apparent conditions for enjoying the blessings of the covenant - faith, repentance and holiness? Is a desire (which is backed by church action) to try and prevent someone from being a hypocrite, from taking false comfort and from bringing discredit on God's church, a deplorable one? Depending on your answer, you will stand in either the Presbyterian or Baptist tradition (using those terms in a broad sense).

On the question of circumcision and baptism I would say just two things. First of all, it is doubtful whether Col. ii. I If. really equates them. The most that can be claimed is an equation of the respective significance of each of them; and 
there is a plausible exegesis of this text which sees in it a contrast between, or a mere juxtaposition of, the two. Secondly, if it is really the case that baptism may be equated with circumcision in meaning, and actually was intended as an equivalent replacement of it, why did Paul never use this argument? Surely it would have been a devastating blow that he could have thrown at the Judaizers who followed him around so persistently. Carefully stated, so as not to give offence to the tender consciences of the Jewish Christians, it would have provided him with the decisive argument against the preachers of another gospel.

Finally, there remains the question of the attitude to be taken towards the children of believers. Are we to regard them as Christians (in the full sense of that term, and surely there is no other) until they specifically deny it by word and/or by life? Or conversely, are we to look upon them as non-Christians until by word and life they specifically deny it? Is their state (not counting the beneficial home influences that will bear upon them) no better than that of the most godless heathen? Dependent upon your answer will be your whole approach to the children's work of the church. How do the responsibilities, duties and potentialities of the children of believers differ from those of the children of unbelievers? Lastly, what distinctive advantage does the child brought up in a godly Paedo-Baptist home enjoy over against the one brought up in a godly Baptist home? These questions are relevant to our subject.

If a justification for this paper be needed, it must be found in the theological confusion which prevails in virtually all denominations on this question of the doctrine of baptism. The writer has found in his own experience that most PaedoBaptists (including many Evangelicals) attempt to justify their practice on considerations which in the last resort resolve themselves into mere sentimentalism or even superstition. Use is all too infrequently made of what in the writer's opinion is the only possible theological justification of infant baptism - the argument from covenant theology. On the other hand Baptists have paid this argument all too scant attention, and theological integrity demands that we come to grips with what is a very cogent and maybe biblical answer to our own position. 